\title{
Taxonomic changes in the genus Dyscia (Lepidoptera: Geometridae: Ennominae)
}

\author{
ROBERT TRUSCH ${ }^{1^{*}}$ and SVEN ERLACHER ${ }^{2}$ \\ ${ }^{1}$ Staatliches Museum für Naturkunde Karlsruhe, Erbprinzenstrasse 13, D-76133 Karlsruhe, Germany; e-mail: trusch@zsm.mwn.de \\ ${ }^{2}$ Institut für Spezielle Zoologie und Evolutionsbiologie mit Phyletischem Museum, Friedrich-Schiller-Universität, Erbertstr. 1, \\ D-07743 Jena, Germany; e-mail: erlacher@pan.zoo.uni-jena.de
}

Key words. Dyscia, taxonomy, revision, species, subspecies, new synonyms, lectotype, neotype, Gnophini, Ennominae, Geometridae, Lepidoptera

\begin{abstract}
This paper presents a revision of the genus Dyscia Hübner, [1825] (Lepidoptera, Geometridae: Ennominae). Examination of types and additional material for most described taxa has resulted in several new synonyms: Dyscia ilivolans Wehrli, 1953 syn. n. and Dyscia duanjiao Yang, 1978 syn. n. are new synonyms of Dyscia fagaria (Thunberg, 1784); Dyscia karsholti Wiltshire, 1991 syn. n. is a new synonym of Dyscia galactaria Turati, 1934; Dyscia dagestana Wehrli, 1934 syn. n. is a new synonym of Dyscia malatyana Wehrli, 1934, and Dyscia rjabovi Wardikjan, 1957 syn. n. is a new synonym of Dyscia negrama Wehrli, 1953. One taxon, formerly treated as a species is reassigned to subspecific level, Dyscia conspersaria ssp. sultanica Wehrli, 1936 stat. rev. Dyscia innocentaria sicanaria (Oberthür, 1923) stat. n. and Dyscia malatyana senecai Wiltshire, 1990 stat. n. are downgraded to subspecies-level. On subspecies-level, Dyscia distinctaria perdistincta Herbulot, 1957 syn. $\mathbf{n}$. is a new synonym of Dyscia distinctaria (Bang-Haas, 1910), Dyscia fagaria alvarensis Wahlgren, 1913 syn. n., Dyscia fagaria albescens Lempke, 1952 syn. n., Dyscia fagaria fusca Lempke, 1952 syn. n., and Dyscia fagaria postdelineata Lempke, 1952 syn. n. are new synonyms of Dyscia fagaria. Dyscia fagaria psoricaria (Eversmann, 1848) syn. n. is a new synonym of Dyscia fagaria favillacearia (Hübner, [1799]), Dyscia holli duponti Thierry-Mieg, 1910 syn. n. is a new synonym of Dyscia holli (Oberthür, 1910), Dyscia malatyana nachadira Brandt, 1941 syn. n. and Dyscia malatyana theodoraria Warnecke, 1941 syn. n. are new synonyms of Dyscia malatyana albersaria Warnecke, 1940 stat. n., and Dyscia penulataria naevata Wehrli, 1953 syn. n. is a new synonym of Dyscia penulataria (Hübner, [1819]). Lectotypes for 22 taxa and neotypes for three taxa - Geometra conspersaria [Denis \& Schiffermüller], 1775, Geometra favillacearia Hübner, [1799], and Geometra emucidaria Hübner, [1813] - are designated. One species is excluded from Dyscia, Thysanopyga serena (Dognin, 1906) comb. n. From a total of 72 previously described taxa, 19 are recognized as species.
\end{abstract}

\section{INTRODUCTION}

The palearctic Gnophini genus Dyscia Hübner, [1825] (Lepidoptera: Geometridae: Ennominae) contains, by present knowledge, 19 species, which occur on steppe land and along the margins of deserts of North-Africa, Arabia, and Asia, and at the south of Europe. Only one species, Dyscia fagaria (Thunberg, 1784), occurs further north to Northwest-Europe as a stenoecic species of open and sandy heaths. The medium-sized moths are nocturnal, and usually of inconspicuous colour. Therefore, numerous species were discovered and described only in the $20^{\text {th }}$ century in the course of the common application of the genital-examination.

The genus Dyscia was established by Hübner ([1825]: 314) for Dyscia conspersaria ([Denis \& Schiffermüller], 1775 ) and Dyscia emucidaria (Hübner, [1813]). For the first time in their catalogues Staudinger (1871) and Staudinger \& Rebel (1901) arranged the species of the palaearctic fauna which are part of Scodiona Boisduval, 1840 (= Dyscia; Hulst, 1896). The first comprehensive representation of the group is found in Prout (1912-1915), who treated all known taxa in the context of his work on the palaearctic geometrid moths. Culot (1919-1920) gave a summary of the European Dyscia species and, for the first time, made notes on the life history of this group. Oberthür (1923) finally dealt with this group.

Mainly taxonomic oriented works by Warnecke (1940-1941, 1941) and Albers \& Warnecke (1940) followed, in which, for the first time, male genital organs as well as a distribution overview were shown for the species of the so called "Dyscia conspersaria F.[sic!]-group". Wehrli (1950) grouped the Dyscia species mainly with features of the male genitalia into altogether eight subgenera. Later he assumed this grouping in his substantial contribution on palaearctic Geometridae (Wehrli, 1953). The only zoogeographic studies which followed were a study by Wiltshire (1990) which contains a tabular survey of the Dyscia species of North African countries, and a study by Erlacher \& Trusch (1999) which deals with the phylogeny and distibution of the "Dysciaconspersaria-group". Herbulot (1981) described a new Dyscia species from Morocco. Wiltshire (1991, 1994) worked on North African and Arabian Dyscia and described the last discovered species in 1986 from Saudi Arabia.

\footnotetext{
* Corresponding author. Tel.: ++49 (0)898107 108; fax: ++49 (0)898107300.
} 


\section{TREATMENT}

\section{Material}

Besides the type material cited here, this study is based on approximately 2.500 collection-based specimens of Dyscia, and the study of the larvae of 12 species, which have been reared from the egg. Some 200 genital slides were made and studied. The deposition of the specimens additionally investigated, and all genital preparations are listed in Trusch \& Erlacher (2001).

\section{Acronyms}

BMNH, The Natural History Museum, London; HERB, coll. C. Herbulot in ZSM; MNHU, Museum für Naturkunde der Humboldt-Universität, Berlin; MNHW, Naturhistorisches Museum, Wien; SMNH, Swedish Museum of Natural History, Stockholm; SMNK, Staatliches Museum für Naturkunde, Karlsruhe; ZFMK, Zoologisches Forschungsinstitut und Museum Alexander Koenig, Bonn; ZISP, Zoological Institute, St.-Petersburg; ZMUA, Zoological Museum University of Amsterdam, Amsterdam; ZMUC, Zoological Museum University of Copenhagen; ZSM, Zoologische Staatssammlung, München.

\section{THE GENUS DYSCIA HÜBNER, [1825]}

The moths of the genus Dyscia can externally be recognised by their characteristic shape. The individuals are medium-sized and coloured from pale grey to beige, with the exception of the reddish Dyscia nobilaria (Bang-Haas, 1906). Unlike other geometrid moths, the outer margin of the forewings is slightly concave. Another external character is the lack of the proboscis (cf. already Hulst, 1896: 366). In the male genitalia, the width to length ratio of the valvae distinguishes two types of genitalia, the high and the wide type (cf. Trusch \& Erlacher, 2001). At the basis of the dorsal margins of the valvae, costal arms emerge medially. A further diagnostic feature is the loss of the uncus. The absence of an uncus occurs also in the genus Aspitates Treitschke, 1825 and Siona Duponchel, 1829. Therefore, this distinguishing mark is not an exclusive apomorphy to the genus Dyscia.

The female genitalia are small and often lacking differentiating features. Its components are for the most part weakly sclerotized. There are two types of corpus bursae, one is weakly sclerotized and the other solid and sculptured, i.e. with very fine tubercles on the inner side of the corpus bursae. The larvae of all species posses a dorsal process on their $9^{\text {th }}$ abdominal segment, except Dyscia nobilaria. In Dyscia penulataria (Hübner, [1819]), this feature is polymorphic, i.e. there are specimens with and without this structure. Finally, in Dyscia lentiscaria (Donzel, 1837) the process is doubled, as an alteration to this character.

Traditionally, the genus Dyscia is placed within the tribe Gnophini (Pierce, 1914, as Gnophinae), which is part of the subfamily Ennominae.

\section{Generic synonymy}

Dyscia Hübner, [1825]: 314. Type species: Geometra conspersaria [Denis \& Schiffermüller], 1775: 106, by subsequent designation (Hulst, 1896: 366), but quoted as conspersaria $\mathrm{F}$., incorrect authorship.

Psednothrix Hübner, [1825]: 320. Type species: Geometra belgiaria Hübner, [1799]: pl. 26, Fig. 140 (synonym of Geometra fagaria Thunberg, 1784), by subsequent designation (Hulst, 1896: 366).

= Maesia Stephens, 1831: 150. Type species: Geometra favillacearia Hübner, [1799]: pl. 26, Fig. 139 (synonym of Geometra fagaria Thunberg, 1784), monotypic.

= Eudyscia Wehrli, 1950: 77. Type species: Geometra fagaria Thunberg, 1784: 7, by original designation.

Scodiona Boisduval, 1840: 185. Type species: Geometra conspersaria [Denis \& Schiffermüller], 1775: 106, by subsequent designation (Hulst, 1896: 366), but quoted as conspersaria $\mathrm{F}$., incorrect authorship.

Zuleika Bang-Haas, 1906: 141-142. Type species: Scodiona nobilaria Bang-Haas, 1906: 141-142, pl. 5, Fig. 13, monotypic.

Warneckeella Wehrli, 1950: 77. Type species: Dyscia malatyana Wehrli, 1934: 535, Fig. 19, by original designation.

Calodyscia Wehrli, 1950: 78. Type species: Scodiona sicanaria Oberthür, 1923: 261, pl. 557, Figs 4780, 4781, by original designation.

Catadyscia Wehrli, 1950: 78. Type species: Dyscia atlantica Reisser, 1933: 49, pl. 11, Figs 1-3, 5-7, by original designation.

Iberafrina Wehrli, 1950: 78. Type species: Geometra penulataria Hübner, [1819] 1796: pl. 98, Figs 507, 508, by original designation.

Rjabovana Wehrli, 1950: 80. Type species: Dyscia negrama Wehrli, 1950: 80, Fig. 6; 1953: 667, pl. 52, Fig. $\mathrm{h}$, by original designation.

\section{Description of the type species Dyscia conspersaria ([Denis \& Schiffermüller], 1775)}

Male. Forewing length $16-21 \mathrm{~mm}$; basal colour whiteyellowish to white-brownish, suffused with dark scales. Melanistic individuals occur, which are sometimes completely brown and lack all markings. Discal spot orbicular or oval, filled with a paler colour, occasionally absent; basal line and postmedian line vary considerably between specimens, ranging from some vein markings to a continuous wavy line; median shadow occurs particularly in specimens from Asia Minor, but occasionally also in the remainder of the species range; suffused spots at the hind margin frequent, in most cases only slightly darker than the basal colour. Hindwing has the same basal colour as forewing; postmedian line continuous on hindwing in the way described above; small central spot point to commashaped, unfilled. Body in basal colour, thorax with paler scales in melanistic individuals. Femora, tibiae, tarsi in basal colour. Underside of wings whitish, partly shiny, the $2 / 3$ towards the anterior margin of forewing brownish. 
Central spots at the ventral side of forewing and hindwing and the outer line marking clear. Antennae bipectinate.

Female. Antennae filiform, otherwise as male.

Male genitalia. Of the high type (cf. Trusch \& Erlacher, 2001). Valvae widened ventrally, especially specimens from Turkey have proximally somewhat lobusshaped outgrowths. Complex of valvae rotated towards the median line, appearing very broad, but distally not widened. Dorsally, the costal arm is broadly attached at the base of the valvae. It is horn-shaped and bent inwards, with one terminal short tooth. Gnathos almost absent, only a very delicate structure. Transtilla proximally connected, the junction as a longitudinal fold, in preparation directed vertically. Saccus regulary rounded. Aedoeagus slender, s-shaped; with a bulge at ductus ejaculatorius; caudal end with two short teeth, otherwise without cornuti.

Female genitalia. Corpus bursae solid and sculptured, i.e. with very fine tubercles at the inner side of the corpus bursae. Ductus bursae tubular and short, about $1 / 4$ length of corpus bursae and of constant diameter (approx. $1 / 2$ of its length). Sterigma of the lamella postvaginalis narrow and high; laterally of this structure a bigger longitudinal fold on both sides, that leads towards the sterigma. On both sides of the ostium bursae are another five smaller longitudinal folds.

\section{The species and subspecies of Dyscia Hübner, [1825]}

\section{Dyscia atlantica Reisser, 1933}

Dyscia (Scodiona) hispanaria ssp. atlantica Reisser, 1933: 49-51, pl. 11, Fig. 1-3, 5-7.

Lectotype $\diamond$, [Morocco], Sidi Chamarouche, Rerayavalley, 2300 m, 28.VI.1932 (H. Dürck) coll. Reisser in coll. SMNK. Hereby designated in order to stabilise nomenclature. Paralectotype $q$, id., 28.VI.1932 (H. Dürck) coll. Reisser in coll. SMNK. One Paralectotype$q$ (id., 2.VII.1932) is missing. Dyscia atlantica was originally described as a subspecies of Scodiona hispanaria Millière, 1866 and elevated to species rank by Zerny (1935: 93).

Additional material examined. $28 \delta \delta, 25 q q$, see appendix in Trusch \& Erlacher (2001).

\section{Dyscia conspersaria conspersaria ([Denis \& Schiffermüller], 1775)}

Geometra conspersaria [Denis \& Schiffermüller], 1775: 106.

Neotype đo, Austria, Wien, Mödling, 28.V.1920 (L. Schwingenschuss), slide No. 86/1996 Erlacher, in coll. ZFMK. According to Art. 75 ICZN hereby designated.

Remarks. According to Article 75 and 76 ICZN, a Neotype is designated with the purpose of clarifying the taxonomic status of Dyscia conspersaria [Denis \& Schiffermüller], 1775, particularly regarding the status of the taxon sultanica Wehrli, 1936. It is common knowledge that the collections of Denis and Schiffermüller were destroyed in Vienna in 1848 (e.g. Horn et al., 1990). The characters differentiating Dyscia conspersaria and the other Dyscia species are described in Trusch \& Erlacher (2001), and the Neotype is figured there, pl. 1, Figs D, E and pl. 4, Fig. C. The relationships between the taxa conspersaria and sultanica are explained in the following.

Ph[alaena] Noct[ua] cuniculina Hübner, 1790: 38, pl. 2/1, Fig. E.

Holotype, [Austria], Vienna district. Synonymised with Fidonia conspersaria by Treitschke (1827: 299). Type material lost.

Phal[aena] Geom[etra] cunicularia Esper, [1803]: 239, pl. 43 , Figs 5,6 .

Syntypes, [Austria], Vienna district and [Italy], area around Florence, ex coll. Gerning. No type material remains in coll. Gerning in state collection of Wiesbaden (Germany) or the coll. Esper in ZSM (cf. Hacker, 1999). Unjustified emendation of cuniculina Hübner, 1790.

Scodiona conspersaria ab. medioumbraria Preissecker, 1930: (17), Fig. 1.

Holotype $q$, [Austria, north-east of Vienna], NeuAigen, Schmidawiesen 23.VI.1928 ([F. Preissecker]) in coll. MNHW (cf. Horn et al., 1990). Infrasubspecific, not available.

\section{Dyscia conspersaria turturaria (Boisduval, 1840)}

Scodiona conspersaria turturaria Boisduval, 1840: 185.

Syntype(s), [France], Digne, July. The Geometrid type material of Boisduval should be in coll. ZFMK, but the type is missing.

\section{Dyscia conspersaria sultanica Wehrli, 1936 stat. rev.}

Dyscia conspersaria ssp. sultanica Wehrli, 1936: 36, pl. 2, Fig. 5.

Lectotype $\delta$, [Turkey], Asia min., Aksehir, Sultan Dagh, 17-2200 m, 1.-15.VII.1934 (E. Pfeiffer), slide No. 85/1996 Erlacher, in coll. ZFMK. Hereby designated in order to stabilise nomenclature. Paralectotypes, id., $1 \delta$ slide No. 7378 Wehrli, id., 1 o slide No. 80/1996 Trusch, id., 8 os in coll. ZFMK.

Remarks. Dyscia sultanica Wehrli, 1936 is treated here as a subspecies of Dyscia conspersaria. Already Albers \& Warnecke (1940:122) had stated that in Asia Minor Dyscia conspersaria occurs, but in the form sultana[sic!]. Wehrli (1953: 659) gave a number of characters which led him to regard sultanica as a species, all of which are, however, gradual and not clearly definable. He indicated a difference in the shape of the costal arm of the valva as well as a wider gnathos and a differently-shaped saccus as characters distinguishing sultanica from conspersaria. Wehrli (1953) subsequently gave the bifurcation at the tip of the costal arm as the only qualitative difference in the genitalia, a feature which is not clear from an examination of his material nor of material examined by the present authors.

This facts are particularly true of animals from Asia Minor which show a wide range of variation (cf. Trusch $\&$ Erlacher, 2001). Thus, in Anatolia there occur not only whitish-brown moths on which the description of sul- 
tanica is based, but also brightly coloured specimens which resemble the European ones and, rarely, completely melanic individuals. Separation of this group of forms from European representatives on the basis of genital differences does not appear to be justified, although in males from Asia Minor the ventral side of the valva shows a small lateral step which has not so far been seen in European material. This structure is very variable but can be stated, according to current knowledge, as a character separating sultanica as a subspecies, unless fresh data calls for a new interpretation, together with the more contrasting pattern of the forewings which also frequently have a median shade. The absence of findings in the Balkans indicates a strong geographical isolation between the populations of Anatolia and Europe. Less is known, however, about the degree of separation of those from the Transcaucasus and Lower Volga.

Additional material of Dyscia conspersaria examined. 99 of $\delta, 79 q 9$, see appendix in Trusch \& Erlacher (2001).

\section{Dyscia crassipunctaria (Rebel, 1916)}

Scodiona conspersaria ssp. crassipunctaria Rebel, 1916: 140, pl. 4, Fig. 5.

Lectotype 9 , Hagia Varvára, 8.V.[1903] (M. Holtz) in coll. NHMW (= Fig. 5, Rebel 1916). Hereby designated in order to stabilise nomenclature. Paralectotypes, Sphakia, 26.III.[1904]: 1 ㅇ, Mélabes, 19.V.[1904]: 1 ơ, (Dörfler), Asitaes, 28.V.[1903]: 1 ઠ, 1 q(M. Holtz), Neapolis, beginning of VI.[1904]: $1 \hat{\delta}$ (H. Rebel), in coll. NHMW. Elevated to species rank by Albers \& Warnecke (1940: 120)

Dyscia crassipunctaria gen. autumn. phthinopora Reisser, 1962: 210, pl. 23, Figs 27-38.

Holotype o (examined), Creta occid., $150 \mathrm{~m}$, Vrysses, 30.IX.1959 in coll. Reisser in SMNK. A large series of paratypes, e.g. Insula Creta, Assites, 800 m, 1.X.1961: 1 o, Ano Archanes, 520 m, Creta centr., 4.X.1961: 1 o, id., Knossos, 150m, 7.X.1959: 1 o, etc., in coll. Reisser in SMNK. Autumn-generation, infrasubspecific, not available.

Additional material examined. 8 os, $9 q q$ plus 520 not individually registered specimens in coll. Reisser in SMNK, see appendix in Trusch \& Erlacher (2001)

\section{Dyscia distinctaria (Bang-Haas, 1910)}

Scodiona lentiscaria var. distinctaria Bang-Haas, 1910: 49.

Lectotype $\hat{o}$, [Spain, north-west of Madrid], San Ildefonso, ex coll. Bang-Haas, in coll. MNHU. Hereby designated in order to stabilise nomenclature. Paralectotype $q$, [id.], ex coll. Bang-Haas, in coll. MNHU. Described with geographic relation. Elevated to species rank by Warnecke (1940-1941: 1047).

Dyscia distinctaria ssp. perdistincta Herbulot, 1957: 191. Syn. n.
Holotype ơ (examined), Espagne, Prov. de Sevilla, Hinojos, 1.IV.1956 ([Y. de Lajonquière]) in coll. HERB in ZSM

Additional material examined. $12 \delta \delta, 4 q \circ$, see appendix in Trusch \& Erlacher (2001).

\section{Dyscia dodonaeeti Wiltshire, 1986}

Dyscia dodonaeeti Wiltshire, 1986: 285, Fig. 109.

Holotype $\delta$ (examined), [Southwest] Saudi Arabia, 80 km N Abhal, Baljurshi, Dodonaea-Juniper Zone, 9.IV.1983 (A. R. Pittaway) coll. Wiltshire in BMNH. Redescription by Wiltshire (1994: 119, 121, Fig. 16; p. 127, Figs 3, 4).

Additional material examined. $6 \delta$, see appendix in Trusch \& Erlacher (2001).

\section{Dyscia fagaria fagaria (Thunberg, 1784)}

Geometra fagaria Thunberg, 1784: 7.

Lectotype ơ, Sweden, Hall.[andia], Osbeck, in coll. Zoological Institute University of Uppsala. Designated by Karsholt \& Nielsen (1985: 444).

Geometra belgaria Hübner, 1790: 92, pl. 4/2, Fig. N.

Syntype(s), Holland [Netherlands]. Synonymised with Scodiona fagaria by Staudinger \& Rebel (1901: 355). Type material lost.

Phalaena Geometra belgiaria [sic!] Borkhausen, 1794: 195-196.

Syntype(s), Belgium. Whereabouts of the type material unknown. Incorrect subsequent spelling, not available. Hübner adopted the incorrect subsequent spelling of Borkhausen (1794): Geometra belgiaria Hübner [1799]: p1. 26, Fig. 140. However, Geometra belgiaria Hübner, [1799] is type species of Psednothrix Hübner, [1825] 1816: 320 , by subsequent designation (Hulst, 1896: 366), and should be mentioned for this reason.

Phalaena mediopunctaria Donovan, 1808: 59, pl. 461, Fig. 1.

Syntype(s), [United Kingdom]. Synonymised by Prout (1915: 408) with Scodiona fagaria. Type material in coll. BMNH (cf. Horn et al., 1990).

Scodiona fagaria var. alvarensis Wahlgren, 1913: 166. Syn. n.

Syntypes $2 \hat{\circ} \approx$, [Sweden], Öland Island, type material probably in coll. Zoological Institute University of Lund (cf. Horn et al., 1990). Infrasubspecific.

Dyscia fagaria (belgiaria) ab. signata Cockayne, 1942: 35 , pl. 2, Fig. 6.

Holotype $q$ (examined), New Forest (F. Gulliver) in coll. BMNH. A melanic individual form of the female. Infrasubspecific, not available.

Dyscia (Eudyscia) fagaria f. albescens Lempke, 1952: 261. Syn. n. 
Syntype(s) o $\delta$, [Netherlands], type material probably in coll. ZMUA (cf. Horn et al., 1990). A whitish form of the male, infrasubspecific.

Dyscia (Eudyscia) fagaria f. fusca Lempke, 1952: 261. Syn. $n$.

Syntype(s) $q 9+$, [Netherlands], type material probably in coll. ZMUA (cf. Horn et al., 1990). A melanic form of the female, infrasubspecific.

Dyscia (Eudyscia) fagaria f. postdelineata Lempke, 1952: 261. Syn. n.

Two Syntype(s) $\partial \hat{\sigma}$, [Netherlands], type material probably in coll. ZMUA (cf. Horn et al., 1990). Individual form, infrasubspecific.

Dyscia fagaria favillacearia (Hübner, [1799]) Geometra favillacearia Hübner, [1799]: pl. 26, Fig. 139.

Neotype $\delta$, Austria inf., [Vienna district], Mödling, 21/4[.19]16 (K. Felkl) in coll. ZFMK. According to Art. 75 ICZN hereby designated. Synonymised by Treitschke (1827: 298) with Geometra belgaria. Change to subspecific status of Scodiona fagaria by Staudinger (1901: $355)$.

Remarks. According to Article 75 and $76 \mathrm{ICZN}$, a Neotype is designated with the purpose of clarifying the taxonomic status of Dyscia fagaria favillacearia (Hübner, [1799]), particularly regarding the status of the taxon psoricaria Eversmann, 1848. It is common knowledge that the Lepidoptera-types of Hübner were destroyed in Vienna in 1848 (e.g. Horn et al., 1990). Dyscia fagaria favillacearia is the geographic race from Central Europe to East Asia.

Boarmia psoricaria Eversmann, 1848: 221. Syn. n.

Lectotype $q$, [Russia, Lower Volga], ([E. Eversmann]), labelled "Calmna", slide No. 97/1996 Trusch, in coll. ZISP. Hereby designated in order to stabilise nomenclature. Paralectotype $\delta$, id., ([E. Eversmann]) in coll. ZISP. Described from one male and one female, the male without abdomen. Synonymised with Scodiona belgaria by Staudinger (1871: 173).

Dyscia fagaria favillacearia ab. fleischmanni Rebel, 1910: (17), Fig. 4.

Holotype o, [Lower Austria], Sollenau, Steinfeld, 5.V.1901 ([F.] Fleischmann), type probably in coll. NHMW (cf. Horn et al., 1990). A melanic male, infrasubspecific, not available.

Dyscia ilivolans Wehrli, 1953: 662. Syn. n.

Lectotype 9 , [China], Kuldja [Yining (Gulja)], 1886 ([H. Christoph]), slide No. 95/1996 Trusch, in coll. ZFMK. Hereby designated in order to stabilise nomenclature. Paralectotype $\delta$, [China/Kasachstan], Ili region, slide No. 7402 Wehrli, in coll. ZFMK.

Remarks. Of Dyscia ilivolans Wehrli, 1953, the female lecto- and the male paralectotype were examined (see above). Further specimens of the taxon have not been identified up to now but may have been mixed up with
Dyscia malatyana (cf. Viidalepp, 1979 and 1988: 142). The two type specimens have been determined as Dyscia fagaria. The differential features given by Wehrli (1953: 662), "gnathos as in malatyana but somewhat shorter and more slender", "saccus as is malatyana" and "costal arm of valva rather "intermediate" " particularly are not correct. Wehrli indicates that "the structure of the genitalia is intermediate between Dyscia malatyana and Dyscia fagaria", which cannot be confirmed here.

There is a wide range of variation in colouring and pattern in Dyscia fagaria. All external characters of the taxon ilivolans given by Wehrli (1953) are described from characteristically aged collection-specimens of Dyscia fagaria, the only material, which was available to Wehrli at the time of his description. Dyscia ilivolans Wehrli, 1953 is therefore synonymized with Dyscia fagaria (Thunberg, 1784). The consubspecific assignment of the taxon ilivolans Wehrli, 1953 to Dyscia fagaria favillacearia Hübner, [1799] is based on the outer phenotype of the specimens, especially the grey-brownish basal colour of the wings and the lack of the elements rich in contrast typical in this subspecies.

Dyscia duanjiao Yang, 1978: 392, pl. 20, Fig. 13. Syn. n.

Holotype $\delta$, [China], Beijing, Huai-rou, Ji-feng-cha village, Ertaizi, 13.V.1977 (Chen Ge-ming) in coll. Agricultural University Bejing.

Remarks. Dyscia duanjiao Yang, 1978 was described from the north-east of China by Yang (1978: 392). Comparing Dyscia duanjiao and Dyscia fagaria, the only one diagnostic character mentioned by Yang (1978) is the shorter antennae of the taxon described by him. The name, duanjiao, is derived from a Chinese word, meaning "short horn", referring in the case to "short antenna". So, the antenna in Dyscia fagaria should be about $2 / 3$ of the length of the forewing costa. In contrast, the antenna in Dyscia duanjiao measures only half this length. The material examined here shows, however, that the length of the antenna in Dyscia fagaria generally is about half the length of the forewing costa (cf. Trusch \& Erlacher, 2001). Furthermore, a smaller discal spot and a different shape of the postmedian line, insignificant differences, are given by Yang (1978) for his material, two males. These supposed differences are within the range of variation of Dyscia fagaria, which varies greatly across its huge distribution area from Western Europe to the Amur. Even the shape of Yang's illustration (1978: pl. 20, Fig. 13) appear identical with Dyscia fagaria, especially in specimens from Mongolia and China examined here (cf. Trusch \& Erlacher, 2001: 81-82). Therefore Dyscia duanjiao Yang, 1978 must be regarded as a junior synonym of Dyscia fagaria (Thunberg, 1784). The consubspecific assignment of the taxon duanjiao Yang, 1978 to Dyscia fagaria favillacearia Hübner, [1799] is based on the outer phenotype of the specimens, see above.

Dyscia fagaria emucidaria (Hübner, [1813])

Geometra emucidaria Hübner, [1813]: pl. 82, Fig. 425. 
Neotype $\delta$, [South France], Basses Alpes, Env. de Digne, 1910 (V. Cotte), slide No. 81/1996 Trusch, in coll. ZFMK. According to Art. 75 ICZN hereby designated.

Remarks. According to Art. $75 \mathrm{ICZN}$, a neotype for the taxon Geometra emucidaria Hübner, [1813] is designated, in order to clarify the taxonomic status of the above cited Fig. 425 of Jacob Hübner. His Lepidopteratypes were destroyed in Vienna in 1848 (e.g. Horn et al., 1990). After a long period, during which the taxon emucidaria was considered to be a good species, a controversy concerning its status began in 1950. Dyscia emucidaria was then synonymised with Dyscia fagaria (Thunberg, 1784) by Lucas (1950: 94), but at that time he did not designate a neotype. Warnecke (1959: 4) then interpreted the questionable illustration of Hübner as a synonym of Dyscia penulataria (Hübner, [1819]). As a result, the common name Dyscia penulataria would become a junior synonym of Dyscia emucidaria. Therefore Warnecke (1959) suggested the conservation of the name penulataria, but he did not invoke the plenary power of the Commission according to article 79 ICZN to suppress the older name emucidaria. Since the type material no longer exists, a further discussion about its identity lacks any scientific basis. Therefore, according to Lucas (1950), Dyscia emucidaria is seen here as representing specimens of Dyscia fagaria from Central and Southwest France, especially since an opinion regarding the identity of Dyscia fagaria and Dyscia emucidaria has already been given in the literature (Hackray et al., 1984). Furthermore, the pointed forewing shape of the individual of Fig. 425 strongly supports the opinion that there has been illustrated a specimen of Dyscia fagaria, and not of Dyscia penulataria, which has more rounded tips to the forewings. The characters which differentiate Dyscia fagaria and the other Dyscia species are described in Trusch \& Erlacher (2001), and the valva of the Neotype of Geometra emucidaria Hübner, [1813] is figured there, pl. 1, Fig. R. The fixation of the taxon Dyscia emucidaria Hübner, [1813] by the neotype designated here should end the controversy concerning the interpretation of this name and prevent the synonymisation of the common name Dyscia penulataria Hübner, [1819].

\section{Dyscia fagaria albidaria (Staudinger, 1871)}

Scodiona fagaria v. (ab.) albidaria Staudinger, 1871: 173.

Lectotype $\delta$, [Western France], Vendée, ex coll. Staudinger, in coll. MNHU. Hereby designated in order to stabilise nomenclature. Paralectotypes, id., $2 \delta \delta, 2$ $q 9$ ex coll. Staudinger, in coll. MNHU. Described with geographic relation, available.

Dyscia fagaria ab. nigerrima Durand, 1934: 170-175.

Holotype o , [Western France], Longeville, 13.IX.1931, coll. Durand not traced. Melanic form of the male. Infrasubspecific, not available.

Additional material of Dyscia fagaria examined. 218 oे, $95 q 9$, see appendix in Trusch \& Erlacher (2001).

\section{Dyscia galactaria Turati, 1934}

Dyscia galactaria Turati, 1934: 180, pl. 3, Fig. 16.

Holotype $q$ (examined), [Libya], Cyrenaica, R. U. Agrario Mechili, $100 \mathrm{~km} \mathrm{~S}$ of Derna, 27.III.[1933?] (G. C. Krüger), slide No. 89/1996 Erlacher, via coll. Wehrli in coll. ZFMK.

Dyscia karsholti Wiltshire, 1991: 90, Figs 1-3. Syn. n.

Holotype $\delta$ (examined), [Tunisia], $20 \mathrm{~km} \mathrm{~S}$ of Gabès, 18.-19.III.1985 (Zool. Mus. Copenhagen Exp.), slide No. WCM.18 Wiltshire, in coll. ZMUC. Paratype o (examined), id., slide No. WCM.15/Geometridae genitalia slide No. 15024, in coll. BMNH.

Remarks. Described from the Libyan Cyrenaika, the female holotype of Dyscia galactaria Turati, 1934 was the only one known specimen of this species until 1998. From the western neighbouring country Tunisia, Dyscia karsholti, of which up to 1997 only two males were known, was described in 1991 by Wiltshire. In 1997, three further males, and in 1998 at last also a female, were captured as a result of two expeditions to Tunisia, done in the context of this work. The comparison of the genital-armature of the female with the holotype of Dyscia galactaria showed, that Dyscia karsholti Wiltshire, 1991 is a junior synonym of Dyscia galactaria Turati, 1934. Altogether, the specimens referred to here are the only ones known to date (cf. Trusch \& Erlacher, 2001).

Additional material examined. $3 \delta \delta, 2 q q$, see appendix in Trusch \& Erlacher (2001).

\section{Dyscia holli (Oberthür, 1910)}

Scodiona holli Oberthür, 1910: 676, pl. 51, Fig. 431.

Holotype $\delta$ (examined), Algeria, Lavarande, 1.V.1908 ([E. Holl]), slide No. Wehrli 7387, ex coll. Wehrli in coll. ZFMK.

Scodiona duponti Thierry-Mieg, 1910: 140. Syn. n.

Holotype + , Algeria, Mascara (Cros). Types probably in coll. Mus. Nation. Hist. Nat. Paris (cf. Horn et al., 1990). A race of Dyscia holli according to Oberthür (1923: 265), treated in subspecific rank (as "var.") of Dyscia holli by Wehrli (1953: 662).

Scodiona albirosea Rothschild, 1911: 232.

Holotype + , Algeria, Bou Saada (V. Faroult) in coll. BMNH. Synonymised with Dyscia holli by Prout (1915: 408).

Scodiona holli f. austauti Oberthür, 1923: 265, pl. 560, Fig. 4810.

Holotype $q$ (examined), Morocco, Moyen Atlas, Kasba Tadla (Alluaud) ex coll. Wehrli in coll. ZFMK. Described as a form of Morocco. Synonymised with Dyscia holli by Zerny (1935: 94).

Additional material examined. $8 \not \hat{\sigma}, 13 q \circ$, see appendix in Trusch \& Erlacher (2001) 
Dyscia innocentaria innocentaria (Christoph, 1885)

Aspilates innocentaria Christoph, 1885: 125, pl. 6, Fig. 5.

Lectotype + , [Turkmenistan], Aschchabad, AchalTekke district, near Nuchur, 16.VI. (H. Christoph), slide No. 96/1996 Trusch, in coll. ZISP. Hereby designated in order to stabilise nomenclature. Only one female is left of the original type material, 1 o and $29 q$ (Lvovsky in litt., 1996).

Dyscia innocentaria sicanaria (Oberthür, 1923) stat. n. Scodiona conspersaria var. sicanaria Oberthür, 1923: 261, pl. 557, Figs 4780, 4781.

Lectotype $q$, Italia, Sicily, 1915 (ex Failla-Tedaldi), slide No. 94/1996 Trusch, via coll. Wehrli in coll. ZFMK. Hereby designated in order to stabilise nomenclature. Paralectotypes, id., 1 o, id. 1908, 2 우, Italia, Sicily, 2 of o, (L. Failla-Tedaldi), via coll. Wehrli in coll. ZFMK. Dyscia sicanaria was originally described as a geographic variation, and elevated to species rank by Warnecke (1941: 209).

Remarks. The synonymy of Dyscia sicanaria (Oberthür, 1923) and Dyscia innocentaria (Christoph, 1885) was made here, had already been suggested by Warnecke (1941: 209, 232). Later, however, Wehrli (1953: 665) gave the opinion that the two forms were specifically different. His reasons, derived exclusively from external features and genitalia of the males examined by him, were

1. A different wing: body proportion and a "marking similar to Perconia". - More than 300 specimens examined during the present study show a wide range of variation in pattern and shape of the wings, and indicate that these are not diagnostic characters (cf. Trusch \& Erlacher, 2001).

2. The ventral process of the valva in Dyscia innocentaria (the eastern form is meant), is shorter, wider, and with more spines on the distal area. - These features appear, however, also in animals examined by us from Italy, the original area of Dyscia sicanaria and the central Asian animals cannot be separated on these characters.

3. In the comparison of Dyscia innocentaria and Dyscia sicanaria, the notch of valva is more shallow, roundedrectangular, not acute-angled. Gnathos shorter and more slender. Aedeagus distally broader, with a more slender distal clasp. Saccus "less deeply concave", its margin nearly straight, caudal with a much weaker lead. - These differences have to be put down to the individual differences in the slides of the two males, examined by Wehrli (artefacts by pressure, cf. slide No. 7375 and 7376 Wehrli in coll. ZFMK).

Further the examination of a number of animals in both sexes from Turkmenistan, Turkey and Italy has also failed to yield specific differences between these animals. None of the alleged differentiating features for the taxon innocentaria given by Wehrli (1953) are diagnostic. Consequently Dyscia innocentaria (Christoph, 1885) is a senior synonym of Dyscia sicanaria (Oberthür, 1923). Because of its more bright basal colour and some differences in the marking of the wings, Dyscia innocentaria sicanaria
(Oberthür, 1923) can be treated as a subspecies of Dyscia innocentaria, its range is South Europe.

S.[codiona] conspersaria scannaria Dannehl, 1933: VII, 146.

Lectotype $\delta$, [Italy], Apenn. Central. M[on]t[a]gna Grande, Scanno, 1000 m, 18.V.[1928] coll. F. Dannehl in coll. ZSM. Hereby designated in order to stabilise nomenclature. Paralectotypes, id., 18.V.[1928] 2 के के, 15.VI.1928 1 §, 18.VI.[1928] 1 §, slide No. 573 Albers, in coll. ZSM. Recognised as Dyscia sicanaria by Warnecke (1941: 234). Spring-generation.

S.[codiona] conspersaria scannaria permutata Dannehl, 1933: 146.

Holotype ô, [Italy], Apenn. Central. M[on]t[a]gna Grande, Scanno, 1000 m, 13.VI.[1928] coll. F. Dannehl, slide No. 583 Albers, in coll. ZSM. Individual form, infrasubspecific, not available.

Dyscia osmanica sicula Reisser in Albers \& Warnecke, 1940: 119.

Lectotype \&, [Italy, Sicily], Mistretta, $1000 \mathrm{~m}$, 17.-25.IX.1938 coll. Reisser in SMNK. Hereby designated in order to stabilise nomenclature. Paralectotypes, id., 34 o o, 14 우, coll. Reisser in SMNK. Assigned to Dyscia sicanaria by Warnecke (1941: 233). Individual form.

Dyscia sicanaria scannaria distinctissima Warnecke, 1941: 234, pl. 27, Fig. 2.

Lectotype $\hat{o}$, [Italy], Apenn. Central. M[on]t[a]gna Grande, 1000 m, [1928] coll. F. Dannehl in coll. ZSM. Hereby designated. Paralectotypes, id., 5.VI.[1928] 1 के slide No. 575 Albers, 7.VII.1928 1 q, 4.IX.[1928] 1 \%, 9.IX.[1928] 3 우, 10.IX.[1928] 1 ㅇ, 11.IX.[1928] 3 우, 12.IX.[1928] 1 \&, 19.IX.[1928] 1 , in coll. ZSM. Infrasubspecific, not available.

\section{Dyscia innocentaria osmanica (Wagner, 1931)}

Scodiona (Dyscia) conspersaria ssp. osmanica Wagner, 1931: 491, pl. 1, Figs 9, 10.

Lectotype $\delta$, [Turkey], Asia min. c., 1.-15.VI. ex coll. Wagner in coll. NHMW. Hereby designated in order to stabilise nomenclature. Paralectotypes, id., 1 ô, id., 6.-31.VI. 1 \&, ex coll. Wagner, in coll. NHMW. Synonymised with Dyscia sicanaria by Warnecke (1941: 209).

Additional material of Dyscia innocentaria examined. 164 $ð \delta, 125 q q$, see appendix in Trusch \& Erlacher (2001).

\section{Dyscia lentiscaria lentiscaria (Donzel, 1837)}

Crocallis lentiscaria Donzel, 1837: 13, pl. 6, Figs 1, 2.

Two Syntypes, of [France], Provence, Hyères, April (M. Foudras); ? id., Monière 15.IV.1829 (M. Cantener \& M. Donzel). Type material has been in coll. Testout (Lyon), and shown by him (1936: 47, pl. 2, Figs 22, 23). Present whereabouts is unknown. 
Dyscia lentiscaria agacles (Oberthür, 1923)

Scodiona lentiscaria f. agacles Oberthür, 1923: 261, pl. 558, Fig. 4782.

Lectotype đo, [Algeria], Guelt-es-Stel, près Boghari, reçu mars and avril 1914 (D. Joseph) ex. coll. Wehrli in coll ZFMK. Hereby designated in order to stabilise nomenclature. Described with geographic relation. Subspecies of Northwest-Africa.

Additional material of Dyscia lentiscaria examined. 62 ô $\delta, 51$ 우, see appendix in Trusch \& Erlacher (2001).

\section{Dyscia leucogrammaria (Püngeler, 1900)}

Scodiona leucogrammaria Püngeler, 1900: 121, p1. 4, Fig. 6.

Lectotype ô, [Turkmenistan], Asia centr., Aschchabad, 20.V.[18]99 ([via R. Tancré]) coll. Püngeler in coll. MNHU. Hereby designated in order to stabilise nomenclature. Paralectotype $\delta$, id., 28.V.[1899], slide No. 736 $\mathrm{Nu} ß$, coll. Püngeler in coll. MNHU.

Additional material examined. $11 \delta \hat{\sigma}, 2 q$, see appendix in Trusch \& Erlacher (2001).

\section{Dyscia malatyana malatyana Wehrli, 1934}

Dyscia malatyana Wehrli, 1934: 535, Fig. 19.

Holotype ơ (examined), [Eastern Turkey], Asia min., Malatya-Tecde, IV (C. Höfer), slide No. 84/1996 Erlacher, in coll. ZFMK. Paratypes, $1 \delta$ (examined) id., 26.V. (C. Höfer), slide No. 7371 Wehrli, in coll. ZFMK; 1 id., 21.V. (C. Höfer) probably in coll. BMNH.

Dyscia plebejaria dagestana Wehrli, 1934: 536, Fig. 20. Syn. n.

Lectotype + , [Russia], Dagestan, Kumtorkale, 25.IX.[1]926 (A. Rjabov), slide No. 82/1996 Trusch, in coll. ZFMK. Hereby designated in order to stabilise nomenclature. Paralectotypes, id. 1 q slide No. 108/1997 Trusch, id., 30.IX.[1]926 1 o slide No. 7372 Wehrli, (A. Rjabov) in coll. ZFMK.

Remarks. In the framework of Wehrli's treatment of the Dyscia-group within the supplementary-volume of "Die Großschmetterlinge der Erde", it had become clear that Dyscia plebejaria (Oberthür, 1910) and Dyscia plebejaria dagestana Wehrli, 1934, originally described without examination of their genital morphology, are not conspecific. However, after dissection of one male, Wehrli (1953: 661; slide No. 7372 Wehrli in coll. ZFMK) elevated dagestana to specific rank, and gave numerous conjectural differences from Dyscia malatyana: 1. male genitalia of dagestana considerably bigger, although the moths smaller, 2. different form of valva, basal half of valva slender, distal part of valva widened and approx. $1 / 3$ larger as in Dyscia malatyana, 3. tegumen of dagestana "distinctly wider", 4. process of valva more strong, 5 . terminal thorn longer, 6. gnathos more slender, and 7 . saccus anteriorly more flattened as in Dyscia malatyana. However, they are inappropriate or already decline within the variability of the material examined by Wehrli himself respectively, as shown by his slides (cf. Dyscia malatyana slide No. 7371, 7393; Dyscia malatyana nachadira slide No. 7410; Dyscia malatyana theodoraria slide No. 7384, and Dyscia malatyana dagestana slide No. 7372, all Wehrli in coll. ZFMK). The characters mentioned above are not clearly definable. With them, no group formation can be carried out in connection with broader features of the animals or their geographical distribution. The high variability of the colouring and pattern of body and wings in Dyscia malatyana does not allow a delimitation on the basis of external characteristics (vs. Wehrli, 1953: 661). As shown from the data of the type material of Dyscia dagestana, these are specimens of the second generation of Dyscia malatyana.

Dyscia malatyana albersaria Warnecke, 1940 stat. $n$. Dyscia albersaria Warnecke, 1940: 1048, pl. 4, Fig. 41.

Holotype ơ, [Turkmenistan], Achal Tekke (H. Christoph), coll. Fixsen in coll. Zool. Mus. Hamburg, destroyed in 1943 (cf. Horn et al., 1990). Synonymised with Dyscia malatyana by Warnecke (1941: 244).

Dyscia malatyana nachadira Brandt, 1941: 883, pl. 30, Fig. 47. Syn. n.

Lectotype $\delta$, Iran, Baloutchistan, street KhachZahedan, Fort Sengan, 1800 m, 30.IV.1938 (Brandt) in coll. SMNH. Hereby designated in order to stabilise nomenclature. Paralectotypes, id., 7 q $q, 1$ s slide No. RMS 133 G. Ebert [preparation missing], 1 ๆ 1938, Kouh i Taftan (Khach), 2000m, 30.IV.1938, 1 , (Brandt), in coll. SMNH; Iran, Baloutchistan, Kouh i Taftan (Khach), 2500m, 29.IV.[1938] 1 o slide No. 7410 Wehrli, id., IV. 1 ㅇ, street Khach-Zahedan, Fort Sengan, 1800 m, 30.IV.1938 1 \%, ex coll. Brandt, in coll. ZFMK; id., 1 o slide No. G 4895 ZSM, ex coll. Hörhammer in coll. ZSM.

Dyscia malatyana f. theodoraria Warnecke, 1941: 245, pl. 28, Figs 3, 4. Syn. n.

Lectotype $\delta[$ Kazakhstan], Semiretshje, Dzarkent [Panfilov] ([H. Christoph]), slide no. 569 Warnecke, in coll. ZSM. Hereby designated in order to stabilise nomenclature. Paralectotypes, 1 T Turkestan, Ili area (coll. Tancré); 2 우, Transcaspien, Aschchabad, in coll. ZSM. $2 \delta \delta$ and $2 q q$ of the type series are missing. An individual form, infrasubspecific.

\section{Dyscia malatyana senecai Wiltshire, 1990 stat. n.}

Dyscia senecai Wiltshire, 1990: 355, Figs 1, 4, 12, 15.

Holotype of (examined), Libya, Gharian, Wadi El Hira, III.1983 (U. Seneca), slide No. 114/1997 Erlacher, in coll. ZMUC. Paratypes (examined), id., $1 \delta, 1 \%$ in coll. BMNH; id., 1 o, 1 \&, both slide No. WCM.10, in coll. ZMUC.

Remarks. As a result of the material examined here, Dyscia senecai Wiltshire, 1990 should no longer be regarded as a good species. In his description, Wiltshire (1990: 355) gave only slight differences in the structure of the aedeagus as differentiating characters, in separating 
his species from the extremely variable Dyscia malatyana. His arguments could not be supported, either by examination of the type material or of the further material studied here (cf. Trusch \& Erlacher, 2001). The sand-yellow coloured animals from Libya, which were available to Wiltshire (1990) for his description of Dyscia senecai, do not show any differences from animals of the "Klapperich-gain" from Jordan examined by Hausmann (1991: 112), for example. These have been determined by Hausmann (1991) as Dyscia malatyana, in agreement with the determination carried out here of the same material. Also, new material collected here from Tunisia, having the phenotype of Wiltshire's senecai, had to be determined as Dyscia malatyana. If the mentioned sandyellow colouring of the specimens from North Africa and the Middle East is seen as an evidence for a good subspecies, senecai can be treated as a subspecies of Dyscia malatyana of this region.

Additional material of Dyscia malatyana examined. 144 ơ ơ, $309 q q$, see appendix in Trusch \& Erlacher (2001).

\section{Dyscia negrama Wehrli, 1950}

Dyscia negrama Wehrli, 1950: 80, Fig. 6.

Lectotype $\delta$, Transkauk., Armen.[ia], fl. [river] Arax, st.[ation] Darasham II, 20.V.[1]934 ([M. A.] Rjabov), slide No. 7392 Wehrli, in coll. ZISP. Hereby designated in order to stabilise nomenclature. Paralectotypes, id., 10 slide No. 115/1996 Erlacher, id., 1 q slide No. 92/1996

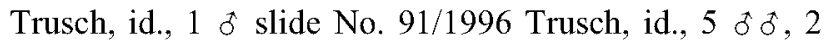
우, [Nachitshevan], Arax, Negram, 19.V.1934: 1 ㅇ, (M. A. Rjabov), in coll. ZFMK ${ }^{1}$. Re-description by Wehrli (1953: 667, pl. 52, Fig. h).

Dyscia rjabovi Wardikjan, 1957: 135, Figs 1, 3. Syn. n.

Holotype $\hat{\sigma}$, Armenia, Oktemberjan district, Cherbeklu, 3.V.1936 (Stscherbakowa) in coll. Zoological Institute, Academy of Sciences of Armenia.

Remarks. The type material of Dyscia rjabovi Wardikjan, 1957 is unavailable at present. However, the identical genital morphology of both taxa already emerges by comparing the figures of Wardikjan (1957: 137, Fig. 3 and 1985: 135, Fig. 1) with those of Wehrli (1950: 79, Abb. 6 ), and the examination of the genital structures here (cf. Trusch \& Erlacher, 2001). Furthermore, there is correspondence in the colouring and at the pattern of the material examined here, the illustrations in Wehrli (1953: pl. 52, Fig. h), and the details at Wardikjan (1957: 135, 136, Fig. 1). Consequently, Dyscia rjabovi Wardikjan, 1957 is a junior synonym of Dyscia negrama Wehrli, 1950.

Beyond this, Wardikjan (1957: 135) notices that there is a "big series of the new species from Nachitschewan, Darasham II, 22.V.1934" in the collection of the Zoological Institut of the Academy of Science of the former USSR. The type series of Dyscia negrama is part of this gain of Rjabov (cf. Wehrli, 1950: 80, Abb. 6 and 1953: 667).
Additional material examined. $7 \delta \delta, 13 q q$, see appendix in Trusch \& Erlacher (2001).

\section{Dyscia nobilaria (Bang-Haas, 1906)}

Scodiona nobilaria Bang-Haas, 1906: 141, pl. 5, Fig. 13.

Lectotype $\delta$, [Tunisia, Gourine, south-east of Gabès] in coll. MNHU. Hereby designated in order to stabilise nomenclature. Paralectotypes, South Oran, ex coll. BangHaas, 1 , in coll. MNHU; id., 1 o (= Fig. 439 Oberthür, 1910) ex B. Haas 1908 in coll. ZFMK. One male of the type series is missing.

Additional material examined. $27 \delta \hat{\delta}, 23 q q$, see appendix in Trusch \& Erlacher (2001).

\section{Dyscia penulataria penulataria (Hübner, [1819])}

Geometra penulataria Hübner, [1819] (1796): pl. 98, Figs 507, 508.

Syntypes, [Southwest-Europe]. Type material lost.

Scodiona hispanaria Millière, 1866: 265, pl. 79, Figs 5-9.

Syntypes, Spain. Type material is possibly in coll. NHMW, however not traceable (cf. Horn et al., 1990). Synonymised with Scodiona penulataria by Staudinger (1871: 174).

Scodiona rubentaria Gumppenberg, 1896: 236, 243.

Described non binominal by Rambur (1866: pl. 17, Fig. 4), validated by Gumppenberg (1896). Holotype $\delta$ (examined), [South-Spain], Granada, ex musaeo P. Rambur, in coll. HERB. Synonymised with Dyscia penulataria by Prout (1915: 408).

Scodiona trabucaria Oberthür, 1923: 265, pl. 560, Figs 4815-4818.

Lectotype $\delta$ (= Fig. 4815 Oberthür), [France], Pyrénées-Orientales, Ille-sur-la-Tet, mi-Septembre 1909 (H. Powell) (23), slide No. Wehrli 7383, via coll. Wehrli in coll. ZFMK. Hereby designated in order to stabilise nomenclature. Paralectotypes, id., 1 \& (=Fig. 4817 Oberthür), id., 1 q (= Fig. 4818 Oberthür), id., St.-Paul-deFenouillet et Grottes de Galamus, Septembre 1909 (H. Powell) (24), 1 o (=Fig. 4816 Oberthür), via coll. Wehrli in coll. ZFMK. Synonymised with Dyscia penulataria by Wehrli (1953: 663).

Dyscia penulataria var. naevata Wehrli, 1953: 664. Syn. n.

Lectotype đ̊, Algeria, Hammam Righa, April 1928 (J. Staettermayer) in coll. ZFMK. Hereby designated in order to stabilise nomenclature. Paralectotypes, id., Mai 1928, 1 o, 1 ㅇ, (J. Staettermayer) in coll. ZFMK. Described by Wehrli (1953) with geographic relation, however, we regard it infrasubspecific.

Dyscia penulataria hispanaria v. eisenbergeri Hörhammer, 1959: 1.

\footnotetext{
${ }^{1}$ For unknown reasons, the type material was retained (cf. Wehrli, 1953: 667). Now, the Lectotype and five of the paralectotypes are given back to ZISP (Stüning, pers. comm.).
} 
Holotype $\delta$, Southern coast of Spain, Villamanrique, 8.-10.V.1956, Paratype $\delta$, id., (Eisenberger), coll. Warnecke in coll. Zool. Mus. Hamburg (cf. Horn et al., 1990). Further Paratypes (examined), id., $7 q 9$ (Eisenberger) in coll. ZSM. Infrasubspecific, not available.

\section{Dyscia penulataria combustaria (Oberthür, 1923)}

Scodiona combustaria Oberthür, 1923: 265, pl. 560, Figs 4811-4814.

Lectotype $\hat{\sigma}$ (= Fig. 4811 Oberthür), Algerie, Lambèse, Avril 1914, (Sari-Amar), slide No. 7389 Wehrli, via coll. Wehrli in coll. ZFMK, designated by Wehrli (1953: 663). Paralectotypes, id., Mai 1912: 1 q (= Fig. 4812 Oberthür), id., e.l. 9.I.1914: 1 \& (= Fig. 4813 Oberthür), (H. Powell), Andalousie, 1 ๆ (= Fig. 4814 Oberthür) ex coll. Boisduval, via coll. Wehrli in coll. ZFMK. Treated as subspecies of Dyscia penulataria of Northwest-Africa by Wehrli (1953: 663).

Additional material of Dyscia penulatoria examined. 69 $\delta \delta, 72 q 9$, see appendix in Trusch \& Erlacher (2001).

\section{Dyscia plebejaria (Oberthür, 1910)}

Zuleika plebejaria Oberthür, 1910: 677, pl. 51, Fig. 437.

Lectotype 9 , [Algeria], Prov. Sebdou, El Aouedje, près Sebdou, 27 et 28 août 1907 (H. Powell) via coll. Wehrli in coll. ZFMK. Designated by Culot (1920: 153, pl. 69, Fig. $1371=$ Fig. 437 Oberthür). Paralectotypes, id., 1 ㅇ slide No. 58/1996 R. Trusch, id., Sebdou, 18.II.1881, 1 o (Codet), slide No. 7373 Wehrli, via coll. Wehrli in coll. ZFMK. The other 14 type specimens are missing.

Enconista nelvaria Oberthür, 1914: 386.

Holotype o, (examined), [Algeria], Batna, 1.IV.[19]13 (Nelva) slide No. 7391 Wehrli, via coll. Wehrli in coll. ZFMK. Synonymised with Dyscia plebejaria by Wiltshire (1990: 354).

Additional material examined. $32 \delta \delta, 8$ 우 $ᄋ$, see appendix in Trusch \& Erlacher (2001).

\section{Dyscia raunaria (Freyer, [1851])}

Cabera raunaria Freyer, [1851]: 160, pl. 582, Figs 3, 4.

Syntypes $\delta$, + , [Slovenia], Karst near Raunach [Ravne near Gorizia]. For the identity of the type locality cf. Hafner (1912: 200): "it is Raunach near St. Peter at the Karst [Sempeter pri Gorici]". The whereabouts of the type material is unknown.

Scodiona conspersaria raunaria ab. integeraria Schawerda, 1920: 97.

Holotype $\$$, Croatia, Zengg. Type material in coll. NHMW (cf. Horn et al., 1990). Whitish form, infrasubspecific, not available.

Scodiona conspersaria raunaria ab. obfuscaria Schawerda, 1920: 97.

Syntypes $\delta \delta$, [Bosnia-Herzegovina], Mostar, 25.V.1914. Type material in coll. NHMW (cf. Horn et al., 1990). Darkened form, infrasubspecific, not available.
Scodiona conspersaria raunaria ab. splichali Hafner, 1912: 200, pl. 2, Fig. 22. Holotype o, [Slovenia], Krain (J. Splichal), present whereabouts of the type is unknown. Infrasubspecific, not available.

Dyscia raunaria vernalis Warnecke, 1941: 232. No type material, name for the first generation. Described as infrasubspecific unit, therefore according to ICZN 46.6.4 not available.

Additional material examined. $57 \delta \delta, 38 q q$, see appendix in Trusch \& Erlacher (2001).

\section{Dyscia rungsi Herbulot, 1981}

Dyscia rungsi Herbulot, 1981: 95, Fig 1.

Holotype of (examined), Maroc, Tuneliat, 25.II.1937, ex coll. Lucas, Paratype $\delta$ (examined), Maroc, ex coll. L. Radot, slide No. 4698 Herbulot, in coll. HERB.

\section{Dyscia simplicaria Rebel, 1939}

Dyscia (Scodiona) simplicaria Rebel, 1939: 539, pl. 15, Fig. 8.

Holotype $\precsim$ (examined), Cyprus, Limassol, 14.IX.1928 (Mavromoustakis) in coll. NHMW. Re-description by Wiltshire (1948: 87, Fig. C).

Additional material examined. $4 \delta \delta, 3 q 9$, see Trusch \& Erlacher (2001).

\section{SPECIES TO BE EXCLUDED FROM THE GENUS DYSCIA HÜBNER, [1825]}

Thysanopyga serena (Dognin, 1906) comb. $n$.

Dyscia serena Dognin, 1906: 118.

Described by Dognin (1906) as a Dyscia-species. For the time being, the taxon is better placed to Thysanopyga Herrich-Schäffer, 1855 (Scoble after Pitkin, in litt., 1998).

\section{CONCLUSIONS}

Since the last review of the group by Wehrli (1953), according to other authors and as a result of this revision, altogether five of the Dyscia taxa hitherto regarded as species have to be synonymised. Wiltshire (1990) synonymised Dyscia nelvaria with Dyscia plebejaria, a revision with which the present authors are in agreement. Lucas (1950: 94) had already assigned Dyscia emucidaria to Dyscia fagaria, but this was ignored in Wehrli's above-mentioned review. Lucas' opinion is substantiated here by the designation of a neotype.

Six further species have been assigned to the genus Dyscia since Wehrli's revision (1953). However, only two of these are confirmed in this paper - Dyscia rungsi and Dyscia dodonaeeti. In this article, Dyscia dagestana and Dyscia senecai are synonymised with Dyscia malatyana, Dyscia ilivolans and Dyscia duanjiao with Dyscia fagaria, and Dyscia sicanaria with Dyscia innocentaria. Dyscia sultanica is restored as a subspecies of Dyscia conspersaria.

So, altogether 28 species-taxa were placed within Dyscia before this study. Of these nineteen remain, five are recognised as new synonyms, two are treated as subspecies of already known species, and one taxon is reas- 
signed to subspecific level. In addition, Dyscia serena (Dognin, 1906), described from South America, is provisionally transferred to Thysanopyga Herrich-Schäffer, 1855.

\section{Synonymic list of valid species-level names in the genus Dyscia, [1825]}

Because a phylogenetic analysis is in preparation (Erlacher \& Trusch in prep.) the reassignment of species is carried out in alphabetical order without assignment to subgenera. The range of the species or subspecies respectively is indicated.

Dyscia atlantica Reisser, 1933 - Morocco

Dyscia conspersaria - Europe up to Asia Minor

Dyscia conspersaria conspersaria ([Denis \& Schiffermüller], 1775) - Southern Central Europe to Eastern Europe

= cuniculina (Hübner, [1790])

= cunicularia (Esper, [1803])

Dyscia conspersaria turturaria (Boisduval, 1840) Southeast-France

Dyscia conspersaria sultanica Wehrli, 1936 stat. rev. Asia Minor

Dyscia crassipunctaria (Rebel, 1916) - Crete

Dyscia distinctaria (Bang-Haas, 1910) - Iberian Peninsula

$=$ perdistincta Herbulot, 1957 syn. n.

Dyscia dodonaeeti Wiltshire, 1986 - Southwest-Arabia

Dyscia fagaria - Europe to East Asia

Dyscia fagaria fagaria (Thunberg, 1784) - Northwest

Europe to Central Europe

= belgaria (Hübner, [1790])

= belgiaria (Borkhausen 1794) (Hübner, [1799])

$=$ mediopunctaria (Donovan, 1808)

= alvarensis (Wahlgren, 1913) syn. n.

= signata Cockayne, 1942

= albescens Lempke, 1952 syn. $\mathbf{n}$.

= fusca Lempke, 1952 syn. $\mathbf{n}$.

= postdelineata Lempke, 1952 syn. $\mathbf{n}$.

Dyscia fagaria favillacearia (Hübner, [1799]) - Central

Europe to East Asia

= psoricaria (Eversmann, 1848) syn. n.

= fleischmanni (Rebel, 1910)

= ilivolans Wehrli, 1953 syn. $\mathbf{n}$.

= duanjiao Yang, 1978 syn. n.

Dyscia fagaria emucidaria (Hübner, [1813]) - Southeast and Central France

Dyscia fagaria albidaria (Staudinger, 1871) - Southwest France

Dyscia galactaria Turati, 1934 - Middle North-Africa

= karsholti Wiltshire, 1991 syn. n.

Dyscia holli (Oberthür, 1910) - Northwest Africa

$=$ duponti (Thierry-Mieg, 1910) syn. n.

= albirosea (Rothschild, 1911)

= austauti (Oberthür, 1923)

Dyscia innocentaria - South Europe to Central Asia
Dyscia innocentaria innocentaria (Christoph, 1885) Central Asia

Dyscia innocentaria sicanaria (Oberthür, 1923) stat. n. - South Europe

= scannaria (Dannehl, 1933)

= sicula Reisser, 1940

Dyscia innocentaria osmanica (Wagner, 1931) - Asia

Minor

Dyscia lentiscaria - Northwest Africa to Southeast

France

Dyscia lentiscaria lentiscaria (Donzel, 1837) - Southwest Europe

Dyscia lentiscaria agacles (Oberthür, 1923) - Northwest Africa

Dyscia leucogrammaria (Püngeler, 1900) - Central Asia

Dyscia malatyana -Palaearctic Southwest to Central Asia and North Arabia to North Africa

Dyscia malatyana malatyana Wehrli, 1934 - Asia

Minor up to the Caspian Sea region

= dagestana Wehrli, 1934 syn. n.

Dyscia malatyana albersaria Warnecke, 1940 stat. n. Central Asia to Iran

= nachadira Brandt, 1941 syn. $\mathbf{n}$.

= theodoraria Warnecke, 1941 syn. n.

Dyscia malatyana senecai Wiltshire, 1990 stat. n. North Africa to North Arabia

Dyscia negrama Wehrli, 1950 - Asia Minor to Central Iran

= rjabovi Wardikjan, 1957 syn. n.

Dyscia nobilaria (Bang-Haas, 1906) - North Africa

Dyscia penulataria - North Africa to South France

Dyscia penulataria penulataria (Hübner, [1819]) Southwest Europe

= hispanaria (Millière, 1866)

= rubentaria (Gumppenberg, 1896)

= trabucaria (Oberthür, 1923)

= naevata $\mathrm{Wehrli}, 1953$ syn. $\mathbf{n}$.

= eisenbergeri Hörhammer, 1959

Dyscia penulataria combustaria (Oberthür, 1923) North Africa

Dyscia plebejaria (Oberthür, 1910) - Northwest Africa

= nelvaria (Oberthür, 1914)

Dyscia raunaria (Freyer, [1851]) - South Europe

Dyscia rungsi Herbulot, 1981 - Morocco

Dyscia simplicaria Rebel, 1933 - Cyprus

ACKNOWLEDGEMENTS. The study was made possible through generous loans and gifts of specimens and material, for which we are indebted to the following colleagues (alphabetically arranged by places): E.P. Wiltshire C.B.E. (Berks, England); Museum für Naturkunde der Humboldt-Universität, Berlin (W. Mey, W. Speidel); Zoologisches Forschungsinstitut und Museum Alexander Koenig, Bonn (C.M. Naumann, D. Stüning); Zoological Museum, University of Copenhagen (O. Karsholt); Deutsches Entomologisches Institut, Eberswalde (H. H. Dathe, R. Gaedike); Forschungsinstitut und Naturmuseum Senckenberg, Frankfurt a. M. (W.A. Nässig); A. Legrain (Hermalle, Belgien); Phyletisches Museum, Jena (D. v. Knorre); Staatliches Museum für Naturkunde, Karlsruhe (G. Ebert); The 
Natural History Museum, London (K. Buckmaster, M. Honey, M. Scoble); Zoologische Staatssammlung, München (A Hausmann, A. Segerer); C. Herbulot (Paris); Transvaal Museum of Natural History, Pretoria (M. Krüger); Zoological Institute, St. Petersburg (A. Lvovsky, V. Mironov); Natural History Museum, Stockholm (B. Gustavsson, T. Pape); Staatliches Museum für Naturkunde, Stuttgart (C.L. Häuser); United States National Museum, Washington (D.C. Ferguson); Naturhistorisches Museum, Wien (M. Lödl). Kindly, the translation of an original-work from the Chinese was carried out by S. Sugi (Tokyo; in litt., 1996). Barry Goater (Chandlers Ford, England) has greatly improved our English. We especially thank two unknown reviewers for their important and helpful suggestions.

\section{REFERENCES}

Albers T. \& WARNecke G. 1940: Vier europäische Arten der Dyscia conspersaria F.[sic!]-Gruppe (Lepidopt. Geometr.). Z. Wien. EntomolVer. 25: 118-122.

BANG-HAAS A. 1906: Neue oder wenig bekannte palaearktische Macrolepidopteren. Dt. Entomol. Z. Iris 19:127-144, pl. 5.

BANG-HAAS A. 1910: Neue oder wenig bekannte palaearktische Macrolepidopteren. Dt. Entomol. Z. Iris 24: 27-51.

Borsduval J.A. 1840: Genera et Index Methodicus Europaeorum Lepidopterorum. Roret, Paris, 238 pp.

BoRKHAUSEN M.P. 1794: Naturgeschichte der Europäischen Schmetterlinge, Vol. 5. Varrentrapp \& Werner, Frankfurt a. M., $572 \mathrm{pp}$.

BRANDT W. 1941: Beitrag zur Lepidopterenfauna von Iran (4) Geometridae. Mitt. Münch. Entomol. Ges. 31: 835-886.

Christopr H. 1885: Lepidoptera aus dem Achal-Tekke-Gebiete. In: Romanoff N.M. (ed.): Mémoires sur les Lépidoptères, Vol. 2. St. Petersburg, pp. 119-171, pl. 6.

Cockarne E.A. 1942: New Aberations of British Macrolepidoptera. Entomol. Rec. J. Var. 54: 33-35.

Culot J. 1919-1920, repr. 1987: Noctuelles et Géomètres d' Europe. Deuxième Partie Géomètres. Apollo Books, Svendborg, 167 pp, pls. $38-70$.

DANNEHL F. 1933: Neues aus meiner Sammlung. (Macrolepidoptera). Entomol. Z. 47: 146-147.

Denis J.N.C.M. \& SCHIFFERMÜlLeR J. 1775: Systematisches Verzeichniss der Schmetterlinge der Wiener Gegend. Beck, Wien, $322 \mathrm{pp}$.

Dognin P. 1906: Hétérocères nouveaux de l'Amérique du Sud. Annls Soc. Entomol. Belg. 50: 106-121.

Donovan E. 1808: The Natural History of British Insects, Vol. 11. Rivington, London, $100+7$ pp., pls 361-396.

Donzel M. 1837: Crocalle du Lentisque. Annls Soc. Entomol. Fr. 13: 13-14, $1 \mathrm{pl}$.

DURAND G. 1934: Variations et aberrations de Lépidoptères. Lambillionea 34: 170-175.

ERLACHER S. \& TRUSCH R. 1999: Zur Phylogenie und Verbreitung der Arten der Dyscia-conspersaria ([Denis \& Schiffermüller] 1775)-Gruppe (= Dyscia s.str.) (Lepidoptera: Geometridae). Courier Forschungsinstitut Senckenberg 215 : 67-81.

EsPer E.J.C. 1803: Die Schmetterlinge in Abbildungen nach der Natur, Vol. 5. Wolfgang Walther, Erlangen, 276 pp, 52 pls.

Eversmann E. 1848: Beschreibung einiger neuen Falter Russlands. Bull. Soc. Imp. Natur. Moscou. 21: 205-232.

FREYER C.F. 1851: Neuere Beiträge zur Schmetterlingskunde, Vol. 6. Rieger, Augsburg, 195 pp, 120 pls.

GAEDIKE R. 1995: Collectiones entomologicae (1961-1994). Nova Suppl. Entomol. 6: 3-83.
GumPPEnBerg C. V. 1896: Systema Geometrarum zonae temperatioris septentrionalis. Vol. 8. Nova Acta Acad. Caesar. Leop. Carol. 65: 215-404, pls 14-18; Halle.

HACKER H.H. 1999: Die Typen der von E.J.Ch. Esper (1742-1810) in seinen "Die Schmetterlinge in Abbildungen nach der Natur" beschriebenen Bombycoidea, Drepanoidea, Geometroidea, Hepialoidea, Lasiocampoidea, Noctuoidea, Pyraloidea, Tineoidea (Lepidoptera) II. Esperiana 7: 443-461.

Hackray J., Sarlet L.G. \& Berger L.A. 1984: Catalogue des Macrolépidoptères de Belgique. Sixième superfamille Geometroidea. Vingt troisième famille Geometridae. Lambillionea 84: 273-288.

HAFNER J. 1912: Verzeichnis der bisher in Krain beobachteten Großschmetterlinge. Carniola, N.F. 3: 77-237.

Hausmann A. 1991: Beitrag zur Geometridenfauna Palästinas: Die Spanner der Klapperich-Ausbeute aus Jordanien (Lepidoptera: Geometridae). Mitt. Münch. Entomol. Ges. 81: 111-163.

Herbulot C. 1957: Nouvelles formes de Geometridae d'Europe occidentale et d'Afrique du nord. Bull. Mens. Soc. Linn. Lyon 26: $190-192$.

Herbulot C. 1981: Un nouveau Dyscia du Maroc (Lep.: Geometridae, Ennominae). Alexanor 12: 95-96.

Herrich-SchäFfer G.A.W. 1855: Sammlung Neuer oder Wenig Bekannter Aussereuropäischer Schmetterlinge. G.J. Manz, Regensburg, $84+18 \mathrm{pp}, 120 \mathrm{pls}$.

Hörhammer C. 1959: Beiträge zur Kenntnis der Gattung Dyscia (Lep.: Geom.): Zur Variationsbreite der Dyscia (subgen. Iberafrina Whli.) penulataria Hb. Opusc. Zool. 34: 1-2.

Horn W.G., Kahle I., Friese G. \& Gaedike R. 1990: Collectiones Entomologicae. 2 Vols. Akademie der Landwirtschaftswissenschaften der DDR, Berlin, $573 \mathrm{pp}$.

HÜBNER J. 1790: Beiträge zur Geschichte der Schmetterlinge, vol. 2(2) \& 2(4). J. Hübner, Augsburg, pp. 33-56, 4 pls. \& pp. $80-100,4$ pls.

HƯBNER J. 1799-1819: Sammlung Europäischer Schmetterlinge, Geometrae. J. Hübner, Augsburg, 113 pls, 596 Figs.

HỨBNER J. 1825: Verzeichnis Bekannter Schmetterlinge. J. Hübner, Augsburg, $431 \mathrm{pp}$.

Hulst G.D. 1896: A classification ot the Geometrina of North America, with descriptions of new genera and species. Trans. Am. Entomol. Soc. 23: 245-386.

ICZN: Internationale Kommission für Zoologische Nomenklatur 2000: Internationale Regeln für die Zoologische Nomenklatur. 4. Ed. Abhandlungen des Naturwissenschaftichen Vereins in Hamburg (NF) 34: 1-232.

Karlsholt O. \& Nielsen E.S. 1985: The Lepidoptera described by C. P. Thunberg. Entomol. Scandinav. 16: 433-463.

KRƯGGer G.C. 1939: Notizie sulla fauna della Sirtica Occidentale: Lepidotteri. Annali Mus. Libico Stor. Nat. 1: 317-357.

LEMPKE B.J. 1952: Catalogus der Niederlandse Macroleoidoptera XI. Tijdsch. Entomol. 95: 197-319.

LuCAS D. 1950: Dyscia emucidaria Hb. (Lep. Geometridae) estelle une bonne espèce? Bull. Mens. Soc. Linn. Lyon 19 : 94-95.

Millière P. 1866: Iconographie et Déscription de Chénilles et Lépidoptères inédites, Vol. 2. Dumoulin, Lyon, 506 pp.

OвеRтнür C. 1910: Explication des planches publiées dans la IVe livraison des Études de Lépidoptérologie comparée. Étud. Lépidoptér. Comp. 4: 676, 677, pl. 51.

OBerthür C. 1914: Description de nouvelles espèces de Lépidoptères d'Algerie. Bull. Soc. Entomol. Fr. 82: 386-387. 
OBERTHÜR C. 1923: Revision iconographique des espèces de Phalénites (Geometra Linné). Étud. Lépidoptér. Comp. 20 261, 265, pls 557, 558, 560 .

Preissecker F. 1930: Lepidopterologische Mitteilungen aus Niederösterreich (Versammlung der Sektion für Lepidopterologie am 7. März 1930). Verh. Zool.-Bot. Ges. Wien 80: $17-18$.

Prout L.B. 1912-1915: Die Gross-Schmetterlinge des Paläarktischen Faunengebietes: Die spannerartigen Nachtfalter. In: Seitz A. (ed.) Die Gross-Schmetterlinge der Erde, I. Abt., 4. Band., Alfred Kernen Verlag, Stuttgart, 479 pp, 25 pls.

PüNGELER R. 1900: Neue Macrolepidopteren aus Central-Asien. Dt. Entomol. Z. Iris 13: 115-123, pl. 4

Rambur J.P. 1866: Catalogue Systematique des Lépidoptères de l'Andalousie. J. B. Baillière, Paris, $412+12$ pp. 22 pls.

Rebel H. 1910: Versammlung der Sektion für Lepidopterologie am 4. Februar 1910. Verh. Zool.-Bot. Ges. Wien 60: 16-18.

ReBel H. 1916: Die Lepidopterenfauna Kretas. Annln Naturh. Hofmus. Wien 30: 66-172, pl. 4.

Rebel H. 1939: Zur Lepidopterenfauna Cyperns. Mitt. Münch. Entomol. Ges. 29: 487-564, pl. 15.

ReIsSER H. 1933: Neue Heteroceren aus dem Großen Atlas. Z. Öst. EntomolVer. 18: 49, pl. 11.

REISSER H. 1962: Weitere neue Heteroceren aus Kreta. Z. Wien Etomol. Ges. 47: 193-216.

Rothschild W. 1911: Some new Algerian Lepidoptera. Ann. Mag. Nat. Hist. (Serie 8) 44: 231-233.

SCHAWERDA K. 1920: Lepidopterologische Mitteilungen. Verh. Zool.-Bot. Ges. Wien 70: 97.

Staudinger O. 1871: Catalog der Lepidopteren des Europäischen Faunengebietes. Burdach, Dresden, $38+200$ pp.

Staudinger O. \& Rebel H. 1901: Catalog der Lepidopteren des Europäischen Faunengebietes, I. Theil. 3. ed. Friedländer \& Sohn, Berlin, $334 \mathrm{pp}$.

StePHens J.F. 1831: A Systematic Catalogue of British Insects, Vol. 2. Baldwin, London, $388 \mathrm{pp}$.

Testout H. 1936: Les types de Lépidoptères décrits par Donzel et Millière et figurant dans la collection Donzel a la "Société Linnéenne de Lyon". Annls Soc. Linn. Lyon 80: 45-71, pl. 2.

ThierRy-Mieg P. 1910: Descriptions de Lépidoptères nouveaux. Le Naturaliste 32: 140-141.

Thunberg C.P. 1784: Dissertatio Entomologica Sistens Insecta Suecica, vol 1. Edman, Uppsala, 24 pp.

Treitschke F. 1827: Die Schmetterlinge von Europa, vol. 6/1 Gerhard Fleischer, Leipzig, 8+444 pp.

Trusch R. \& ERlacher S. 2001: Zur Morphologie, Verbreitung, Bionomie und Identifikation der Dyscia-Arten (Lepidoptera, Geometridae: Ennominae). Bonner Zoologische Monografien No. 49, 116 pp., 12 pls.

Turati E. 1934: Novità di Lepidotterologia in Cirenaica, IV. Atti Soc. Ital. Sci. Nat. Mus. Civ. Stor. Nat. Milano 73 : 159-212, pl. 3 .

VIIDALEPP J. 1979: List of Geometrid Moths (Lepidoptera, Geometridae) of the fauna of the USSR IV. Entomol. Obozr. 58: $782-799$
VIIDALEPP J. 1988: Fauna of Geometridae of the Mountains of Central Asia. Nauka, Moskau, 240 pp. [in Russian]

WAGNER F. 1931: Dritter (IV.) Beitrag zur Lepidopteren-Fauna Inner-Anatoliens. Int. Entomol. Z. 24: 475-493, 1 pl.

WAHLGREN E. 1913: Neue Schmetterlingsformen aus dem Alvargebiete der Insel Öland. Entomol. Tijdsch. 34: 164-167.

WARDIKJAN S.A. 1957: New species of geometrid moths of the genus Dyscia Hbn. (Lepidoptera: Geometridae) from Armenian SSR. Dokl. Akad. Nauk Armyan. SSR 24: 135-139.

WARDIKJAN S.A. 1985: Atlas of Genital Apparatus of Geometrid Moths (Lepidoptera: Geometridae) of the Armenian SSR. Acad. Sci. Armenia, Erewan, 136 pp.

WarNecke G. 1940-1941: Zur Kenntnis der Gattung Dyscia Hb. (Lep. Geom.). Mitt. Münch. Entomol. Ges. 30: 1047-1051; 1941: 31: pl. 4.

WARNeCKe G. 1941: Ein weiterer Beitrag zur Kenntnis der Dyscia conspersaria F.-Gruppe (Lep. Geometr.). Z. Wien. Entomol. Ges. 26: 208-211, 231-235, 241-246, pls 27, 28.

WARnecKe G. 1959: Beiträge zur Kenntnis der Gattung Dyscia (Lep. Geom.): Was ist Dyscia (Scodiona) emucidaria Hübner 425 nec Duponchel. Opusc. Zool. 34: 3-5.

Werrur E. 1934: Über neue palaearktische Geometrinae und ein neues Subgenus (Lep.: Heterocera). Int. Entomol. Z. 27: 533-536, Figs 19, 20.

WehruI E. 1936: Einige neue Arten und Rassen aus den Ausbeuten des Herrn Ernst Pfeiffer, München. Mitt. Münch. Entomol. Ges. 26: 33-37, pl. 2.

Wehru E. 1950: Die Einteilung der Gattung Dyscia. Entomol. Berich. 13: 77-80.

WeHrLI E. 1953: Die Spanner des Paläarktischen Faunengebietes, Suppl. zu Band 4: Die spannerartigen Nachtfalter. In: Seitz A. (ed.): Die Gross-Schmetterlinge der Erde, I. Abt., Alfred Kernen Verlag, Stuttgart, pp. 657-668, pls 52, 53.

WILtSHIRE E.P. 1948: Middle East Lepidoptera, IX: Two New Forms or Species and Thirty-Five New Records from Cyprus. Entomol. Rec. J. Var. 60: 79-87.

Wiltshire E.P. 1986: Lepidoptera of Saudi Arabia: Fam. Cossidae, Sesiidae, Metarbelidae, Lasiocampidae, Sphingidae, Geometridae, Lymantriidae, Arctiidae, Nolidae, Noctuidae (Heterocera); Fam. Satyridae (Rhopalocera) (Part 5). Fauna of Saudi Arabia 8: 262-323.

Wiltshire E.P. 1990: Dyscia senecai sp. n. from Libya, with notes on some other N. African Dyscia species (Geometridae, Ennominae). Nota Lepidopter. 12: 354-365.

WiltshiRe E.P. 1991: Dyscia karsholti sp. n., from Tunisia (Lepidoptera: Geometridae, Ennominae). Nota Lepidopter. 14: 90-93.

WiLTSHIRE E.P. 1994: Arabian Lepidoptera: a supplement to the catalogue of Saudi Arabian Macro-Heterocera. Fauna of Saudi Arabia 14: 113-136.

YANG C. 1978: Moths of North China, Vol. 2. Agricultural University, Peking, pp. 301-527. [in Chinese]

ZERNY H. 1935: Lepidopterenfauna des Großen Atlas in Marokko und seiner Randgebiete. Mémoires Soc. Sci. Nat. Maroc 42: 1-163.

Received September 18, 2001; revised April 23, 2002; accepted April 23, 2002 